\title{
Les sarcophages en grès du Bourbonnais : production, diffusion
}

\section{Sophie Liegard}

\section{(2) OpenEdition \\ Journals}

Édition électronique

URL : http://journals.openedition.org/adlfi/5898

ISSN : 2114-0502

Éditeur

Ministère de la culture

Référence électronique

Sophie Liegard, «Les sarcophages en grès du Bourbonnais : production, diffusion », ADLFI. Archéologie de la France - Informations [En ligne], Auvergne, mis en ligne le 01 mars 2007, consulté le 19 avril 2019. URL : http://journals.openedition.org/adlfi/5898

Ce document a été généré automatiquement le 19 avril 2019

(c) Ministère de la Culture et de la Communication, CNRS 


\title{
Les sarcophages en grès $\mathrm{du}$ Bourbonnais : production, diffusion
}

\author{
Sophie Liegard
}

\author{
Identifiant de l'opération archéologique : 129
}

Date de l'opération : 2005 - 2007 (PC)

1 L'année 2007 constitue la dernière année de ce PCR pluriannuel (BSR 2004, p. 32-34; BSR 2005, p. 35-36 ; BSR 2006, p. 35, Sophie Liegard) qui a mobilisé une quarantaine de participants issus de tous horizons. Cette année 2007 a permis l'achèvement de l'inventaire des sarcophages en grès des départements de l'Allier et de la Creuse; quarante-six lieux de découvertes (dont deux dans le Creuse) ont ainsi été identifiés. Les recensements dans les départements du Cher, de l'Eure-et-Loir, du Loiret, du Loir-et-Cher et de la Nièvre ont été poursuivis, sans toutefois pouvoir être menés à leur terme.

2 En ce qui concerne les carrières, près d'une vingtaine de lieux d'extraction de grès a été étudiée parmi la cinquantaine visitée. Certains d'entre eux conservent encore des traces d'exploitations illustrant le savoir-faire des carriers (Fig. $n^{\circ} 1:$ La Desphiliponne: trace de havage) et (Fig. $n^{\circ} 2:$ La Desphiliponne : emboitures). Une première typologie des carrières de grès peut aujourd'hui être proposée (Fig. $\mathrm{n}^{\circ} 3$ : Proposition de typologie des carrières d'extraction de grès), en attendant la suite des prospections.

3 Les analyses pétrographiques ont été poursuivies afin de caractériser le mieux possible les roches utilisées pour la fabrication de ces sarcophages du haut Moyen Âge. De nouvelles méthodes d'analyses pourraient être mises en œuvre prochainement dans le même but.

4 Toujours dans le cadre de ce PCR, une journée d'étude a été organisée, en novembre 2007, sur le thème du grès. Cette réunion s'est tenue à Coulandon avec le soutien de la municipalité. Elle a permis de rassembler une trentaine de géologues, géographes, archéologues, historiens, historiens de l'art et tailleurs de pierre qui, à l'issue des débats, ont pu visiter une carrière de grès locale. 
5 Les travaux engagés lors de ce PCR n'étant pas achevés, l'équipe envisage, à partir de 2008, de poursuivre les recherches dans le cadre de deux nouveaux PCR : le premier, rattaché à l'Auvergne, devrait porter sur le recensement et l'étude des carrières de grès permiens de l'Allier et le second, rattaché à la région Centre, devrait viser à compléter l'inventaire des sarcophages en grès produits dans l'Allier et exportés dans cette région et dans l'ouest de la Bourgogne.

6 Liegard Sophie

\section{ANNEXES}

Fig. $\mathrm{n}^{\circ} 1$ : La Desphiliponne : trace de havage

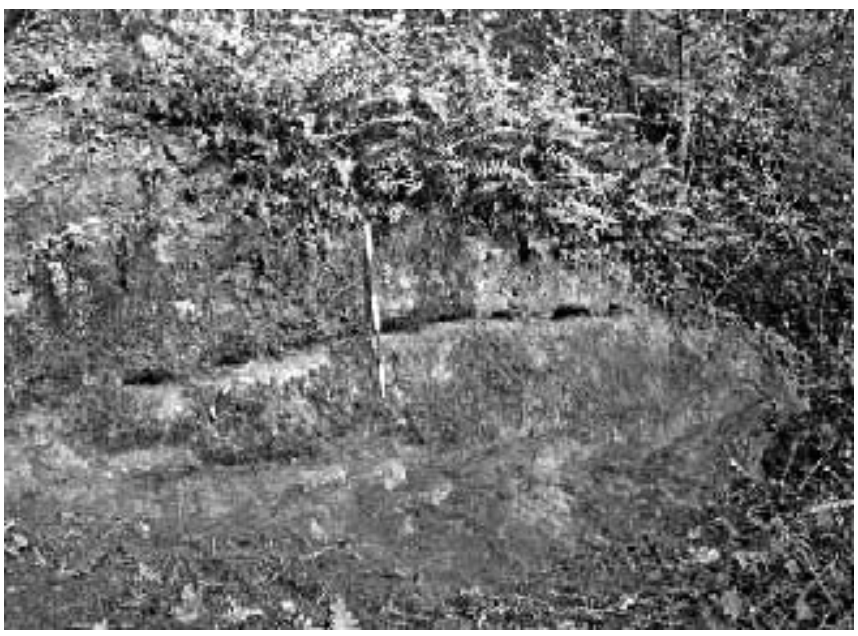

Auteur(s) : Liegard, Sophie (INRAP). Crédits : Liegard, Sophie (2007) 
Fig. $n^{\circ} 2$ : La Desphiliponne : emboitures

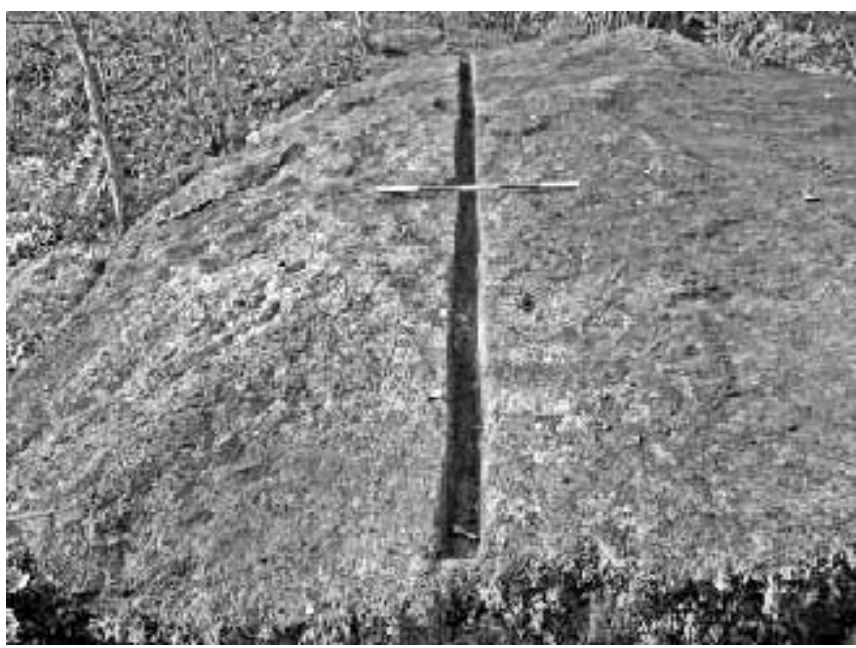

Auteur(s) : Liegard, Sophie (INRAP). Crédits : Liegard, Sophie (2007)

Fig. $n^{\circ} 3$ : Proposition de typologie des carrières d'extraction de grès

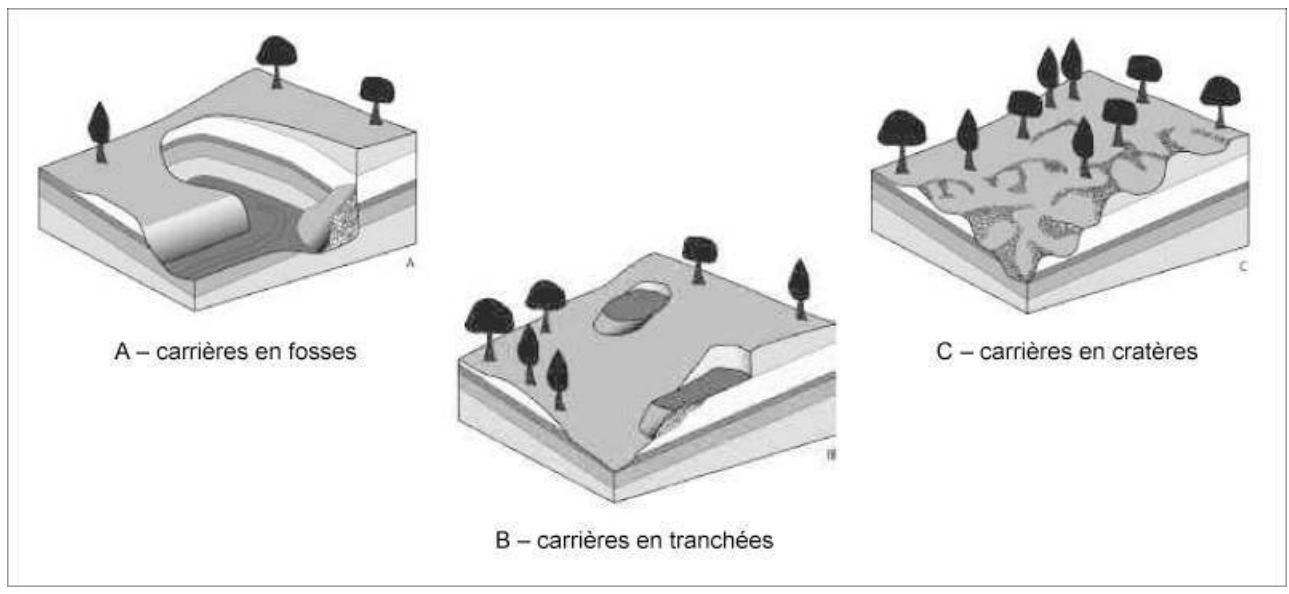

Auteur(s) : Fourvel, Alain. Crédits : Fourvel, Alain (2007)

INDEX

Index géographique : Auvergne, Allier (03), Coulandon

Index chronologique : Moyen Âge

operation Projet collectif de recherche (PCR)

Thèmes : acquisition de ressource naturelle, carrier, carrière, exploitation, grès, inventaire, pétrographie, recensement, sarcophage

\section{AUTEURS}

SOPHIE LIEGARD

INRAP 